\title{
ELUTION OF AN INCOMPLETE TYPE OF ANTIBODY FROM THE ERYTHROCYTES IN ACQUIRED HAEMOLYTIC ANAEMIA
}

\author{
BY \\ P. KIDD \\ From the London Hospital Medical College
}

(RECEIVED FOR PUBLICATION, AUGUST 21, 1948)

A notable advance in the study of the haemolytic anaemias was made by Boorman, Dodd, and Loutit (1946), who showed that it was possible to differentiate between the congenital and acquired types of acholuric jaundice by submitting the washed erythrocytes from these patients to the action of an anti-human globulin serum (Coombs and others, 1945). The erythrocytes of 17 patients with congenital familial type were not agglutinated under these conditions, whereas those from seven patients with clinically acquired type were all agglutinated and so presumably had antibody globulin adsorbed to their surface. No free antibody was found in the serum from these cases, probably because all circulating antibody was fixed on the erythrocytes.

During a personal study of six patients with acquired haemolytic anaemia the washed erythrocytes of all cases were found to agglutinate strongly with an anti-human globulin serum. Corresponding antibody of the "incomplete" type (Race, 1944) was not, however, found free in the serum of any of these cases, although cold agglutinin of low titre was present in the serum of two of them. In order to elucidate further the nature of the antibody adsorbed upon the erythrocyte in these patients it seemed necessary to attempt to dissociate the antibody from its union with the erythrocyte. After a number of tentative experi- $c$ ments a satisfactory technique for this purpose was elaborated, and the results presented provide direct evidence that an antibody of "incomplete" type is adsorbed on the erythrocytes in these cases. Some in vitro properties of this antibody were also investigated.

\section{Materials and Methods}

A brief summary of the pertinent clinical and haematological findings in the patients studied is given in Table $I$. Venous blood samples were obtained with a dry syringe and immediately defibrinated by stirring with a glass rod. Samples were examined before and after splenectomy in Case 4. In the remaining cases all the samples examined were collected at varying intervals after splenectomy had been performed.

TABLE I

MAIN CLINICAL AND HAEMATOLOGICAL FINDINGS IN SIX CASES OF ACQUIRED HAEMOLYTIC ANAEMIA

\begin{tabular}{|c|c|c|c|c|c|c|c|c|c|c|}
\hline Case & Age & Sex & $\begin{array}{l}\text { Red cells } \\
10^{6} \text { per } \\
\text { c.mm. }\end{array}$ & $\begin{array}{l}\text { Haemo- } \\
\text { globin } \\
\text { per cent } \\
\text { (Haldane) }\end{array}$ & $\begin{array}{l}\text { Reticulo- } \\
\text { cytes } \\
\text { per cent }\end{array}$ & $\begin{array}{l}\text { Serum } \\
\text { bilirubin } \\
\text { mg. per } \\
100 \mathrm{ml} .\end{array}$ & $\begin{array}{l}\text { Osmotic } \\
\text { fragility. }\end{array}$ & $\begin{array}{l}\text { Auto- } \\
\text { agglu- } \\
\text { tination }\end{array}$ & $\begin{array}{c}\text { Direct } \\
\text { Race - } \\
\text { Coombs } \\
\text { test }\end{array}$ & $\begin{array}{c}\text { Treat- } \\
\text { ment }\end{array}$ \\
\hline 1 & 74 & $\mathbf{M}$ & 2.8 & 60. & 30.0 & 3.2 & Slightly & Absent & +++ & Spl. \\
\hline 2 & $\begin{array}{l}33 \\
66\end{array}$ & $\begin{array}{l}\mathbf{M} \\
\mathbf{F}\end{array}$ & 1.66 & $\begin{array}{l}30 \\
36\end{array}$ & 6.4 & 3.6 & $\begin{array}{l}\text { Normal } \\
\text { Normal }\end{array}$ & $\begin{array}{c}\text { Absent } \\
\text { Present } \\
\text { (trace) }\end{array}$ & $\begin{array}{l}+++ \\
+++\end{array}$ & $\begin{array}{l}\text { Spl. } \\
\text { Spl. }\end{array}$ \\
\hline 4 & -43 & $\mathbf{F}$ & 1.0 & 32 & 18.0 & 3.6 & Normal & $\begin{array}{l}\text { Present } \\
\text { (marked) }\end{array}$ & +++ & Spl. \\
\hline $\begin{array}{l}5 \\
6\end{array}$ & $\begin{array}{l}46 \\
28\end{array}$ & $\begin{array}{l}\mathbf{F} \\
\mathbf{M}\end{array}$ & $\begin{array}{l}2.85 \\
2.5\end{array}$ & $\begin{array}{l}71 \\
52\end{array}$ & $\begin{array}{l}11.8 \\
15.0\end{array}$ & $\begin{array}{l}2.0 \\
2.8\end{array}$ & $\begin{array}{l}\text { Normal } \\
\text { Normal }\end{array}$ & $\begin{array}{l}\text { Absent } \\
\text { Absent }\end{array}$ & $\begin{array}{l}+++ \\
+++\end{array}$ & $\begin{array}{l}\text { Spl. } \\
\text { Spl. }\end{array}$ \\
\hline
\end{tabular}


Anti-human globulin serum.-Rabbits were immunized with two doses of the globulin precipitate from $7.5 \mathrm{ml}$. of Group $O$ human serum dialysed against distilled water for forty-eight hours, followed by two doses of $1 \mathrm{ml}$. of whole serum. The injections w\$re given into the ear vein at five-day intervals and the animals bled seven to ten days after the last injection. After suitable adsorption with a mixture of packed washed human erythrocytes of Groups A, B, and $\mathrm{O}$, the working dilution of the serum was found by testing it against erythrocytes sensitized with a serum containing incomplete anti-Rh antibody. A dilution of $1 / 20$ to $1 / 40$ gave rapid agglutination of the test cells at $37^{\circ} \mathrm{C}$.

pH measurements. - These were made with the glass electrode unless otherwise stated.

Citrate-HCl buffer $\mathrm{M} / 10$ (Sörensen). $-p H \quad 3.2$ to 3.4. This was prepared according to the directions given by Clark (1928).

Elution of antibody. - This was effected by a modification of the procedure used by Landsteiner and van der Scheer (1936) to dissociate azostromataantibody complexes. The dilute acetic acid used by these workers was replaced by $\mathrm{M} / 10$ citrate- $\mathrm{HCl}$ buffer at $p \mathrm{H} 3.2$ to 3.4. The procedure adopted was as follows. $20-50 \mathrm{ml}$. of whole blood was centrifuged, the plasma removed, and the erythrocytes washed three times with physiological saline. An equal volume of distilled water was then added to the packed cells and the mixture lysed by repeated freezing and thawing. Erythrocyte stroma was then prepared according to the principle of Jorpes (1932). The lysed blood was diluted with a further five volumes of distilled water and the stroma precipitated by adjustment of the mixture to $p \mathrm{H} 5.6$ to 5.8 by addition of the minimal necessary quantity of $\mathrm{N} \mathrm{HCl}$. The precipitate removed by gentle centrifugation was then freed as far as possib'e of haemoglobin by repeated washing with $M / 15$ phosphate buffer at pH 5.6 to 5.8. To one volume of washed packed stromata was then added 2 to 3 volumes of the citrate- $\mathrm{HCl}$ buffer, and after thorough mixing the
pH was readjusted, if necessary, to between $p H$ 3. and 3.4 by the addition of $\mathrm{N} / 1 \mathrm{HCl}$. After leavingthe mixture for 10 or 15 minutes at room tempera ture the stromata were separated by centrifugation? and the supernatant removed and rapidly adjusted to $p \mathrm{H} 7.2$ to 7.4 by the dropwise addition of $5 \mathrm{~N} \mathrm{NaOHog}$ using phenol red as an external indicator. During neutralization a heavy precipitate of stroma proteiñ separated, carrying down with it most of the residual colour in the solution. This precipitate was removed? and the supernatant eluate, now practically co'our $\overrightarrow{0}$ less or faintly tinged with the brown colour of acidhaematin, was stored in the frozen state in screw $\vec{\omega}$ capped bottles over dry carbon dioxide ice.

Testing of the eluates.-Serial dilutions were mades in physiological saline and two drops of each dilution mixed with two drops of a 2 per cent suspension ofv washed human erythrocytes in small test tubes. 15 comparative tests of titre the erythrocytes of the samev Group $\mathbf{O}$ donor were used throughout.

After incubation for one hour at $37^{\circ} \mathrm{C}$. the erythro= cytes were washed twice with physiological saline and resuspended to approximately 2 per cent concentra tion, and then two drops of a suitably diluted antihuman globulin serum added to each tube. After further 30 minutes in the incubator the tests were reado by gently shaking each tube, and the results recorded on a rough quantitative scale:

$+++=$ Large compact clumps

$+=$ Clumps just visible to the naked eye

A control of washed 2 per cent unsensitized cells plusi two drops of anti-human globulin serum was included in each test.

\section{Results}

Range of erythrocytes affected.-The eluates? have been found to react with all human erythro cytes tested ; that is to say exposure of the erythro? cytes to the eluate results in the "coating" of the erythrocytes with an antibody so that the cells are rendered agglutinable after washing and addition

TABLE II

EFFECT OF ELUATES ON VARIOUS TYPES OF ER YTHROCYTES

( 1 vol. eluate +1 vol. 2 per cent erythrocyte suspension incubated for 1 hour at $37^{\circ} \mathrm{C}$. Cells washed three times with saline. Anti-human globulin serum added.)

\begin{tabular}{|c|c|c|c|c|c|c|c|c|c|c|c|c|c|}
\hline \multirow{2}{*}{$\begin{array}{c}\text { Source } \\
\text { of } \\
\text { eluate }\end{array}$} & \multicolumn{4}{|c|}{$\begin{array}{l}\text { Blood group of } \\
\text { human erythrocytes }\end{array}$} & \multirow{2}{*}{ 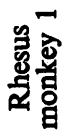 } & \multirow{2}{*}{ 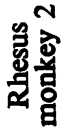 } & \multirow[t]{2}{*}{ Mouse } & \multirow[t]{2}{*}{$\begin{array}{l}\text { Guinea } \\
\text { pig }\end{array}$} & \multirow[t]{2}{*}{$\underset{\text { bit }}{\text { Rab- }}$} & \multirow[t]{2}{*}{ Rat } & \multirow[t]{2}{*}{ Fow } & \multirow[t]{2}{*}{ Horse } & \multirow{2}{*}{ 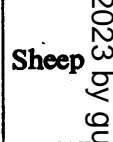 } \\
\hline & $\mathbf{A}$ & B & ORht & ORh' - & & & & & & & & & \\
\hline $\begin{array}{c}\text { Case } 1 \\
\text {," } 2 \\
\text { ", } 4 \\
y\end{array}$ & $\begin{array}{l}+++ \\
+++ \\
+++ \\
+++\end{array}$ & $\begin{array}{l}+++ \\
+++ \\
+++ \\
+++\end{array}$ & $\begin{array}{l}+++ \\
+++ \\
+++ \\
+++\end{array}$ & $\begin{array}{l}+++ \\
+++ \\
++t \\
+++\end{array}$ & + & + & E & $\begin{array}{l}- \\
-\end{array}$ & E & $\begin{array}{l}- \\
-\end{array}$ & - & - & $\begin{array}{r}-8 \\
- \\
- \\
\end{array}$ \\
\hline $\begin{array}{ll} & 5 \\
. & 6\end{array}$ & $\begin{array}{l}++t \\
++t\end{array}$ & $\begin{array}{l}+t+ \\
t+t\end{array}$ & $\begin{array}{l}+++ \\
++t\end{array}$ & $\begin{array}{l}+++ \\
+++\end{array}$ & & & & & & & & & \\
\hline
\end{tabular}


of an anti-human globulin serum. This effect is quite independent of the $\mathrm{ABO}$ and Rhesus group of the erythrocytes concerned. To date no human red cell has been found which cannot be fully "coated" or sensitized by exposure to the action of these eluates.

There was no appreciable difference in the degree of sensitization of erythrocytes from the different blood groups by any given eluate. It is concluded, therefore, that the cell receptor involved has no relation to any of the known blood group receptors. It is of interest to note that the erythrocytes from two cases of familial acholuric jaundice were rendered fully agglutinable in anti-human globulin serum by exposure to the eluates from Cases 1 to 4 .

Some of the eluates were tested. against a range of animal erythrocytes. In no case were any of the erythrocytes sensitized, with the exception of two samples of Rhesus monkey cells; in this instance the agglutination in anti-human globulin serum after exposure to the eluate was very much weaker that in the case of human erythrocytes.

The results are tabulated in Table II.

Titre of the eluates.- The titre of the different eluates was determined using the erythrocytes of the same Group $\mathbf{O}$ donor. The results are shown in Table III. In addition the nitrogen content of three of the eluates, obtained by the microKjeldahl procedure, is recorded in $\mathrm{mg}$. $\mathrm{N}_{2}$ per $100 \mathrm{ml}$.

\section{TABLE III}

TITRES OF ELUATES AGAINST GROUP O ERYTHROCYTES FROM THE SAME DONOR

\begin{tabular}{|c|c|c|}
\hline Eluate & $\begin{array}{l}\text { Range of titres obtained } \\
\text { with different preparations }\end{array}$ & $\begin{array}{l}\text { Nitrogen content } \\
\text { mg. per } 100 \mathrm{ml} \text {. }\end{array}$ \\
\hline $\begin{array}{cc}\text { Case } & 1 \\
,, & 2 \\
\text {, } & 3 \\
\text {," } & 4 \\
\text {, } & 5 \\
\text {," } & 6\end{array}$ & $\begin{array}{l}1 / 32 \text { to } 1 / 256 \\
\text { Not tested } \\
1 / 32 \text { to } 1 / 128 \\
1 / 4 \text { to } 1 / 16 \\
1 / 64 \text { to } 1 / 128 \\
1 / 16 \text { to } 1 / 64\end{array}$ & $\begin{array}{l}19.6 \\
32.0\end{array}$ \\
\hline
\end{tabular}

Thermal amplitude. - The eluates proved to have a wide thermal amplitude. Sensitization after holding the eluate and erythrocyte mixture at $40^{\circ} \mathrm{C}$. room temperature, and $37^{\circ} \mathrm{C}$., seemed equally strong as judged by the degree of agglutination on subsequently suspending the washed erythrocytes in anti-human globulin serum.

Between the limits of $40^{\circ} \mathrm{C}$. and $37^{\circ} \mathrm{C}$., therefore, union of antibody and erythrocytes seems little affected by the temperature at which sensitization is allowed to take place.
Effect of the eluates on the osmotic fragility of normal erythrocytes. - None of the cases studied showed any marked increase of osmotic fragility in hypotonic saline. The two strongest eluates from Case 1 and Case 3 were therefore selected for use in these experiments. The experimental procedure followed is illustrated by the following experiment using eluate from Case $1.0 .25 \mathrm{ml}$. washed, packed, normal Group $\mathbf{O}$ erythrocytes plus $0.75 \mathrm{ml}$. eluate were incubated for one hour at $37^{\circ} \mathrm{C}$. After washing three times with physiological saline and packing by centrifugation, $0.1 \mathrm{ml}$. saline was added to the deposit. Strong sensitization of the erythrocytes was confirmed at this stage by the finding of rapid agglutination of the erythrocytes on testing with anti-human globulin serum. A control of $0.25 \mathrm{ml}$. packed erythrocytes plus $0.75 \mathrm{ml}$. physiological saline was taken through the same manipulations. After thorough mixing $0.02 \mathrm{ml}$. aliquots of the two cell mixtures were distributed into a range of tubes containing $5 \mathrm{ml}$. quantities of hypotonic saline ranging from 0.3 to $0.7 \mathrm{~g}$. per $100 \mathrm{ml}$. in steps of $0.05 \mathrm{~g}$. per $100 \mathrm{ml}$., and a tube for complete haemolysis containing $5 \mathrm{ml}$. of 0.4 per cent ammonia. After standing for two hours at room temperature all tubes were centrifuged for ten minutes at 2,500 r.p.m. and the optical density of the supernatant was then measured in a photo-electric colorimeter using an Ilford 604 filter. The percentage haemolysis in each tube was then calculated. As a result of a number of similar experiments it was found that exposure of normal erythrocytes to the eluates from Case 1 and Case 3, even when the erythrocytes were sensitized in the presence of the patient's fresh serum, did not significantly alter their resistance to hypotonic saline.

Action of the eluates in the presence of complement.-It was obviously of interest to determine whether normal erythrocytes fully sensitized by these eluates would be haemolysed on addition of complement. It was soon found that the amount of citrate present in the eluates was sufficient to inactivate 6 to 8 M.H.D. of complement. The tests were therefore conducted by allowing the erythrocytes to react with the eluates for one hour in the $37^{\circ} \mathrm{C}$. waterbath, after which they were washed three times with saline to remove all traces of buffer, and resuspended to 2.5 per cent concentration. To $0.25 \mathrm{ml}$. of the sensitized red cell suspension $0.5 \mathrm{ml}$. physiological saline and $0.25 \mathrm{ml}$. of complement dilutions containing 3 and 6 M.H.D. were then added, and the tubes kept at $37^{\circ} \mathrm{C}$. for two hours and then at $4^{\circ} \mathrm{C}$. for eighteen hours overnight. On removal from the ice chest the 
tubes were shaken, lightly centrifuged, and examined for the presence of haemolysis. Two controls were always included:

1. $0.25 \mathrm{ml}$. sensitized cells $+0.5 \mathrm{ml}$. saline +0.25 ml. 6 M.H.D. complement dilution previously inactivated for 30 minutes at $56^{\circ} \mathrm{C}$.

2. $0.25 \mathrm{ml}$. unsensitized cells $+0.5 \mathrm{ml}$. saline + $0.25 \mathrm{ml}$. 6 M.H.D. active complement.

In Cases 1 and 2 and Cases 5 and 6 the results were unequivocal. No haemolysis was ever produced under the conditions of the experiment. In Cases 3 and 4, however, the eluates proved capable of causing haemolysis in the presence of complement. Qualitative experiments showed nearly complete haemolysis with 6 M.H.D. and partial haemolysis with 3 M.H.D. of complement. Quantitative estimation of the haemoglobin in the supernatant fluid in the two experiments showed with the eluate from Case 394 per cent haemolysis with 6 M.H.D. and 73 per cent haemolysis with 3 M.H.D. of complement. However, in this case the control tube containing sensitized cells plus inactivated complement also showed 20 per cent haemolysis, although the tube containing unsensitized cells plus 6 M.H.D. active complement showed no haemolysis.

Similarly in Case 46 M.H.D. complement gave 52 per cent haemolysis and 3 M.H.D. 19 per cent, whereas the control with inactivated complement plus sensitized cells showed 5 per cent haemolysis. The control with unsensitized cells plus 6 M.H.D. active complement again showed no haemolysis. Thus the haemolysis produced in these experiments could not have been entirely dependent on the complement activity of the guinea-pig serum, although obviously increasing the dose of complement increased the total haemolysis produced. The complete absence of haemolysis with 6 M.H.D. of complement and unsensitized cells showed that the effect could not have been due to any antihuman red cell heterolysin present in the dilutions of guinea-pig serum used.

The eluates used in both these experiments had been stored in sealed screw-capped bottles over dry carbon dioxide ice for six months. Some haemolytic activity developing on storage and not related to the antibody content of the eluate obviously cannot be excluded. Unfortunately by the time these experiments were completed neither of the patients was available for further study so that these findings could not be confirmed with fresh eluates. On the suggestion of Dr. J. V. Dacie erythrocytes fully sensitized with eluates from Case 1 and Cases 5 and 6 were suspended in fresh human serum acidified with graded doses of $0.5 \mathrm{ml}$. quantities of serum were acidified wit屡 $0.05 \mathrm{ml}$. of $\mathrm{N} / 10, \mathrm{~N} / 5, \mathrm{~N} / 4, \mathrm{~N} / 3.5, \mathrm{~N} / 3$, and $\mathrm{N} / 2.5 \mathrm{HCl}$ respectively. To these aliquots of acidified serum was then added $0.05 \mathrm{~m}$. of 5 每 per cent washed Group $O$ erythrocyte suspensio previously fully sensitized with the eluate unde? test. After two hours at $37^{\circ} \mathrm{C}$. the tubes wer lightly centrifuged and the supernatant serurb examined for the presence of haemolysis. $\mathrm{No}$ haemolysis was found under these conditions withy any of the eluates used.

Blocking experiments.-In order to test the hypothesis that the antibody present in thesies eluates might be the "incomplete" form of the cold agglutinin present in the serum of some caseg of acquired haemolytic anaemia the following experiment was carried out.

Two per cent washed Group $O$ erythrocytes wer sensitized with sufficient eluate to render the cells fully saturated with antibody as judged by imo mediate maximal agglutination on suspending sample of the washed erythrocytes in anti-humai globulin serum and the demonstration of residua antibody in the supernatant eluate. Three lots of erythrocytes sensitized with eluates from Cases 5 , and 6, and the same unsensitized erythrocytes? were then made up to 2 per cent suspension and used in the titration of a serum from a case of chronic haemolytic anaemia known to contain high-titre cold agglutinin. After addition of the erythrocyte suspensions to a range of serial serum dilutions the tubes were placed in the ice chest $4^{\circ} \mathrm{C}$. for 18 hours. On removal from the ice ches the tubes were lightly shaken and the results read. macroscopically and microscopically. The eng point was taken as the last tube showing definite microscopic agglutination. The final titres obtained with the four lots of erythrocyte suspen? sions are shown in Table IV. The final titres obtained differ by only one tube and there therefore no evidence that the action of the colf

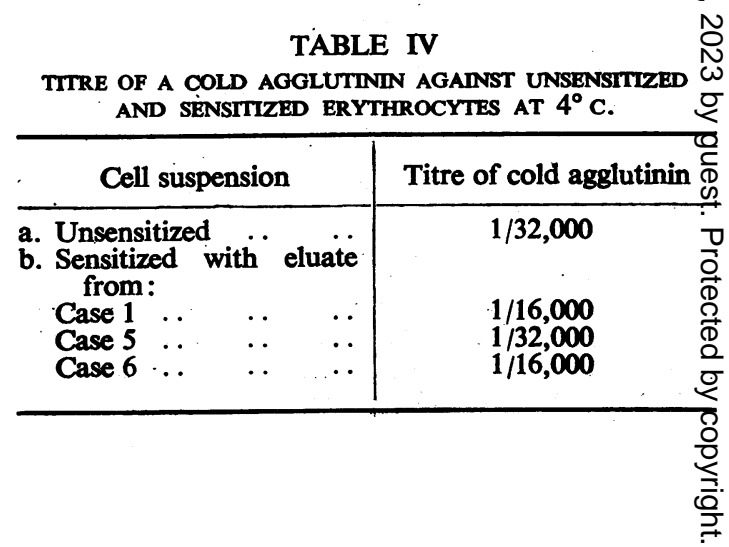


agglutinin on the erythrocyte was blocked by previously "coating" the erythrocyte with antibody of the type present in these eluates.

\section{Discussion}

Since the present work was begun two papers have appeared in which the elution of antibody in acquired haemolytic anaemia is described. Evans and others (1946) adduced evidence that the erythrocytes in two cases of acquired haemolytic anaemia were coated with an immune body which could be released and transferred to normal cells in vitro. Eluates were prepared from the washed erythrocytes of the patients by exposing them to the action of saline at $56^{\circ} \mathrm{C}$. It was found that normal cells were sensitized by these eluates only if the cell-eluate mixtures were kept at $5^{\circ} \mathrm{C}$. overnight and the agglutinability in anti-human globulin serum was improved by holding the cell-eluate mixtures for two hours at $37^{\circ} \mathrm{C}$. after their removal from the ice chest. After five minutes at $56^{\circ} \mathrm{C}$. the patients' washed cells were rendered inagglutinable in anti-human globulin serum, presumably because of elution of the adsorbed antibody. The authors further noted agglutination of the patients' cells in 30 per cent bovine albumin and 2 per cent acacia, but not in normal human serum. No serum antibodies were detected in the first patient studied. In the second patient cold agglutinin to a titre of $1 / 32$ and an atypical agglutinin active against about 30 per cent of Group $O$ cells irrespective of Rhesus and MN grouping was found in the serum before any blood transfusion had been given.

Sturgeon (1947) demonstrated an incomplete or blocking type of antibody in the serum of three patients with acquired haemolytic anaemia with the aid of anti-human globulin serum. The titre of free antibody ranged between $1 / 128$ and 1/4,096 in the cases studied. In one case a high titre saline eluate was prepared by incubating the patient's cells or sensitized normal cells in equal volumes of saline for 30 minutes at $37^{\circ} \mathrm{C}$. or $56^{\circ} \mathrm{C}$. This was shown to react with cells of all four groups, including Rhesus-positive and Rhesus-negative cells. It did not react with Rhesus monkey cells or with sheep's cells. Cells strongly sensitized with the eluate still reacted with anti-A, anti-B, and anti-Rh sera in the normal way, thus showing that these receptors were not blocked by the new antibody. Normal cells stored for a few days in saline could not be sensitized by the eluate. The antibody was not reduced in potency by exposure to $70^{\circ} \mathrm{C}$. for ten minutes, but could not be demonstrated by the indirect developing test after ten minutes at $80^{\circ} \mathrm{C}$. The antibody appeared to be an auto-antibody and a pan-antibody, but did not react with Rhesus monkey cells.

The present work confirms many of these findings but there are a number of disagreements in detail. In all the cases studied it was possible by means of the acid buffer elution technique now described to elute an immune body from the erythrocytes which was capable of sensitizing or "coating" normal erythrocytes irrespective of their ABO or Rhesus groups and thus rendering them agglutinable, after washing with saline, in an anti-human globulin serum. Between the limits of $4^{\circ} \mathrm{C}$. and $37^{\circ} \mathrm{C}$., union of antibody and erythrocyte was not affected by the temperature at which the eluate and erythrocyte mixture was held before washing and addition of anti-human globulin serum. The eluates did not sensitize the erythrocytes of laboratory animals, with the exception of Rhesus monkey cells tested in two instances.

Saturation of normal Group $\mathbf{O}$ erythrocytes with the antibody contained in the two highest titre eluates did not alter their osmotic resistance to hypotonic saline. The reaction of normal Group $O$ erythrocytes fully sensitized by eluates from Cases $1,2,5$, and 6 in the presence of fresh guinea-pig serum and fresh human serum suitably acidified was clear-cut. No haemolysis was ever found under these conditions. Using the eluates from Cases 3 and 4, however, haemolysis was consistently produced in the presence of guinea-pig complement, but the experiments were complicated by the finding of some degree of haemolysis in the presence of a 6 M.H.D. complement dilution inactivated by heating for thirty minutes at $56^{\circ} \mathrm{C}$. The complete absence of haemolysis of unsensitized cells suspended in the same dilution of active complement was held to exclude the presence of any anti-human heterolysin in the dilutions of guineapig serum used. The possibility that this effect was related to prolonged storage of the eluates in the frozen state is considered.

A limited experiment showed that saturation of normal erythrocytes with the antibody contained in the eluate from three of the cases did not block the action on the erythrocytes of a high-titre cold agglutinin present in the serum of a patient with chronic haemolytic anaemia.

The experiments reported show that the immune body present in these eluates reacts with a broad antigen present in all human red cells and to a lesser extent in Rhesus monkey cells. Although direct evidence cannot be produced on this point it seems likely that the cell receptor involved is closely related to the human species-specific receptor reacted upon by anti-human red cell sera pre- 
pared in other species. The general behaviour of the antibody, apart from its broader specificity, shows a close resemblance to that of the "incomplete " antiRh antibody and especially to that form designated "cryptagglutinoid" by Hill and others (1948).

In contrast to the findings of Sturgeon (1947) and Neber and Dameshek (1947) using 30 per cent bovine albumin no free antibody of "incomplete" type could be demonstrated in the serum of any of the present cases using the anti-human globulin serum technique.

The in vitro reactions, as in the case of the "incomplete" anti-Rh antibody, shed little light on the mechanisms by which haemolysis is produced in vivo. Much further work is required on this question, and it is hoped that the elution technique outlined may help in such investigations.

\section{Summary}

1. A technique is outlined whereby an antibody of "incomplete" type can be eluted from the erythrocytes in acquired haemolytic anaemia.
2. The properties and in vitro reactions of sum eluates are described and discussed with reference to previously published findings.

I am indebted to a number of clinicians for accefs to their cases, to Dr. J. F. Loutit and Dr. J. V. Dagje for blood samples and much helpful advice, and $\$$ Dr. F. O. McCallum for Rhesus monkey cells.

\section{REFERENCES}

Boorman, K. E., Dodd, B. E., and Loutit, J. F. (1946). Lancet, 1, $8 \overrightarrow{12}$ Clark, W. M. (1928). "The Determination of Hydrogen Ions" London: Baillière, Tindall, and Cox. Third Edit., p. 209. Coombs, R. R. A., Mourant, A. E., and Race, R. R. (1945). B. J. exp. Path., 26, 255.

Dacie, J. V., and Richardson, N. (1943). J. Path. Bact., 55, 375. N Evans, R. S., Duane, R. T., and Behrendt, V. (1946). Proc. Soc. exp. Biol., N.Y., 64, 372.

Hill, J. M., Haberman, S., and Jones, F. (1948). Blood, Speciel Issue No. 2: "The Rh Factor in the Clinic and the Laboratorg" New York: Grune and Stratton, p. 80.

Jorpes, E. (1932). Bio-hem. J., 26, 1488.

Landsteiner, K., and van der Scheer, J. (1936). J. exp. Med., 63, 325.

Neter, J., and Dameshek, W. (1947). Blood, 2, 371.

Race, R. R. (1944). Nature, 153, 771.

Sturgeon, P. (1947). Science, 106, 293. 